\title{
火災加熱を受けるスギ・カラマツ構造用集成材柱の座屈耐力および破壞時間 BUCKLING STRENGTH AND FAILURE TIME OF JAPANESE CEDAR AND LARCH GLUED LAMINATED TIMBER COLUMNS EXPOSED TO FIRE
}

\author{
五十嵐 樹*1, 石井俊 吾*2, 山下平祐*3, \\ 馬場重彰*4, 染谷朝 幸*5, 平島岳夫*6 \\ Tatsuki IGARASHI, Shungo ISHII, Heisuke YAMASHITA, \\ Shigeaki BABA, Tomoyuki SOMEYA and Takeo HIRASHIMA
}

\begin{abstract}
This paper reports on results of load-bearing fire test of structural glued laminated timber columns with Japanese cedar and larch during not only heating phase but also cooling phase. The purpose of the tests was to confirm the properties of charring, the temperature distribution in the cross-section, the deformation behavior and the failure time. The failure time from the test result was compared with that of the calculated result by the buckling strength on the basis of tangent modulus theory and mechanical properties at high temperature in accordance with Eurocode5.
\end{abstract}

Keywords: Structural glued laminated timber, Fire, Column, Failure time, Buckling Strength, Load-bearing fire test 構造用集成材, 火災, 柱, 破壊時間, 座屈耐力, 載荷加熱実験

\section{1. はじめに}

火災時における木質構造の構造安定性を検討寸るには、鉛直荷重 を支持する柱・梁の火災時耐力を見積もる必要がある。防火被覆が 施されない準耐火建築物の柱・梁では、要求される耐火時間に応じ て燃えしろ深さを部材断面から減じ、残りの非炭化部分で常温構造 設計を行うことで荷重支持能力を確保するとされている 11 。しかし ながら火災時には建物内部の可燃物が燃え尽きた後にも木質構造の 断面内温度が上昇するため、火災減衰期において梁の耐力がさらに 半減する可能性などが報告されている 2)。木質構造の柱が火災に曝 されると、炭化に伴う非炭化領域の断面二次モーメントの減少が著 しく、細長比が大きくなるため、座屈によって破壊する危険性があ る。火災時における柱の座屈破壊は、構造物の倒壊につながり、火 災減衰期にまで消火活動を続ける消防隊員の人命に関わる問題であ る。したがって防火被覆を施さない木質構造で大規模建築物を造る には、柱の火災時破壞時間を予測する手法を確立する必要がある。

構造用集成材による柱の耐火性については、炭化深さに関するデ 一夕はある程度蓄積されており 3 、一般的な傾向としては密度が大 きな木材ほど耐火性に優れることが知られている。構造的な検討と しては所定の時間までの変形量と荷重支持能力を確認した中村らの 研究 4) 等はあるが、破壊に至るまでの挙動を把握して柱の火災時耐
力を検討した研究は少ない。木造柱の火災時耐力に関しては、火災 加熱を受けて炭化した断面を想定した柱の常温圧縮試験結果と柱を 有する木造土壁の載荷加熱実験結果を比較・検討した安井らの研究 5)、さらにヤング係数の低下を考慮した清水らの研究 6) があり、炭 化後の断面による弾性曲げ座屈荷重に基づき柱の火災時耐力を予測 できる可能性が報告されている。これらの研究では、細長比が比較 的大きな柱を対象としたため弾性曲げ座屈荷重で耐力を概社予測で きる範囲にあり、加熱開始から 45 分までの準耐火性能について検 討された。一方、大断面木材による柱が 1 時間以上の火災加熱を受 けた場合でその減衰期の変形挙動までを調べた載荷加熱実験は皆無 であり、火災加熱を受ける大断面構造用集成材の柱の破壊時間を予 測する方法は未だ確立されていない。

そこで本研究では、大断面の構造用集成材による柱を対象とした 載荷加熱実験を行い, 標準的な火災加熱を受けた場合の炭化性状・ 断面内温度・変形挙動・破壊性状について, 加熱終了後の炉内放冷 過程での挙動も含めて明らかにする。火炎加熱を受ける柱の破壊時 間に及ぼす影響要因として、断面寸法・加熱時間・荷重条件を取り 上げ、国産材のスギとカラマツの 2 種について比較・検討する。ま た、その実験結果に合わせるように断面内部温度を数值解析によっ て与え、Eurocode5 の高温時力学的特性および接線係数理論に基づ

\footnotetext{
*1 千葉大学大学院融合理工学府 大学院生

*2 構造計画研究所 修士 (工学) (元千葉大学大学院生)

*3 (一財) 建材試験センター 博士 (工学)

*4 大成建設(株技術センター 博士 (工学)

*5 (株) 日建設計 博士 (工学)

$* 6$ 千葉大学大学院工学研究院 教授・博士 (工学)
}

Grad. Student, Graduate School of Sci. and Eng., Chiba Univ.

Kozo Keikaku Engineering Inc., M.Eng. (Former Grad. Student, Chiba Univ.)

Japan Testing Center for Construction Materials, Dr.Eng.

Taisei Advanced Center of Technology, Taisei Corporation, Dr.Eng

Nikken Sekkei Ltd., Dr.Eng.

Prof., Graduate School of Engineering, Chiba Univ., Dr.Eng. 
く座屈耐力計算による破壊時間と実験值の比較を行い、柱の火災時 破壊時間を予測するための 1 つの手法を提案する。

\section{2. 実験概要}

\section{1 実験条件および試験体}

載荷加熱実験の条件を Table 1 に示す。試験体は全部で 20 体と し、カラマツ構造用集成材による柱(以下、カラマツ柱)を 10 体、ス ギ構造用集成材による柱(以下、スギ柱)を 10 体とした。実験変数は、 樹種(カラマツ・スギ)、断面寸法 $(300 \mathrm{~mm}$ 角・ $450 \mathrm{~mm}$ 角)、加熱時間 (30 分・ 60 分・90 分)、長期許容荷重に対する軸力の比 $(1 \cdot 2 / 3 \cdot 1 / 3$; 以下、荷重比と称す)の 4 つとし、それぞれの違いによる影響を検討 した。試験体名の一例を挙げると、L300-60-1 は、カラマツの 300 角断面、60 分加熱、荷重比 1 の試験体である。Table 1 において、 *がついている試験体に関しては、断面内温度を把握するための熱 電対を挿入した。

Table 1 Test parameters

\begin{tabular}{|c|c|c|c|c|}
\hline $\begin{array}{l}\text { Specimen } \\
\text { name }\end{array}$ & $\begin{array}{c}\text { Tree } \\
\text { species }\end{array}$ & $\begin{array}{l}\text { Cross-sectional } \\
\text { dimension }[\mathrm{mm}]\end{array}$ & $\mid \begin{array}{c}\text { Heating } \\
\text { time }[\mathrm{min}]\end{array}$ & $\begin{array}{l}\text { Load } \\
\text { ratio }\end{array}$ \\
\hline L300-30-1* & \multirow{10}{*}{$\begin{array}{c}\text { Japanese } \\
\text { Larch } \\
\text { (カラマツ) }\end{array}$} & \multirow{5}{*}{$300 \times 300 \mathrm{~mm}$} & \multirow{2}{*}{30} & 1 \\
\hline L300-30-2/3 & & & & $2 / 3$ \\
\hline L300-60-1 & & & \multirow{3}{*}{60} & 1 \\
\hline L300-60-2/3 & & & & $2 / 3$ \\
\hline L300-60-1/3* & & & & $1 / 3$ \\
\hline L450-60-1 & & \multirow{5}{*}{$450 \times 450 \mathrm{~mm}$} & \multirow{2}{*}{60} & 1 \\
\hline L450-60-1/3* & & & & $1 / 3$ \\
\hline L450-90-1 & & & \multirow{3}{*}{90} & 1 \\
\hline L450-90-2/3* & & & & $2 / 3$ \\
\hline L450-90-1/3 & & & & $1 / 3$ \\
\hline C300-30-1 & \multirow{10}{*}{$\begin{array}{c}\text { Japanese } \\
\text { Cedar } \\
(\text { スギ) }\end{array}$} & \multirow{5}{*}{$300 \times 300 \mathrm{~mm}$} & \multirow{2}{*}{30} & 1 \\
\hline C300-30-2/3* & & & & $2 / 3$ \\
\hline C300-60-1 & & & \multirow{3}{*}{60} & 1 \\
\hline C300-60-2/3 & & & & $2 / 3$ \\
\hline C300-60-1/3* & & & & $1 / 3$ \\
\hline C450-60-1 & & \multirow{5}{*}{$450 \times 450 \mathrm{~mm}$} & \multirow{2}{*}{60} & 1 \\
\hline C450-60-1/3* & & & & $1 / 3$ \\
\hline C450-90-1 & & & \multirow{3}{*}{90} & 1 \\
\hline C450-90-2/3 & & & & $2 / 3$ \\
\hline C450-90-1/3* & & & & $1 / 3$ \\
\hline
\end{tabular}

* Thermocouples inserted

Table 2 Specifications of specimens

\begin{tabular}{|c||c|c|}
\hline \multicolumn{1}{|c||}{ Tree species } & Japanese Larch & Japanese Cedar \\
\hline \hline Strength grade & E95-F315 & E65-F255 \\
\hline Length & \multicolumn{2}{|c|}{$3,300 \mathrm{~mm}$} \\
\hline Lamination & \multicolumn{2}{|c|}{ Thickness $30 \mathrm{~mm}$} \\
\hline Lamination grade & L100 & L70 \\
\hline Adhesive & \multicolumn{2}{|c|}{ Resorcinol phenol resin } \\
\hline Oven-dry & $0.520(300 \times 300)$ & $0.371(300 \times 300)$ \\
density [g/cmi] & $0.505 \sim 0.539$ & $0.330 \sim 0.400$ \\
(Cross-section) & $0.534(450 \times 450)$ & $0.347(450 \times 450)$ \\
min max & $0.513 \sim 0.563$ & $0.331 \sim 0.370$ \\
\hline Moisture content [\%] & $11.6(300 \times 300)$ & $11.3(300 \times 300)$ \\
(Cross-section) & $10.5 \sim 12.2$ & $11.1 \sim 11.7$ \\
min $\sim \max$ & $10.4(450 \times 450)$ & $11.5(450 \times 450)$ \\
& $9.9 \sim 11.0$ & $11.3 \sim 11.9$ \\
\hline
\end{tabular}

試験体の概要を Table 2 に示す。同一等級構造用集成材を使用し、 強度等級はカラマツ柱で E95-F315、スギ柱で E65-F255 である。 試験体長さは $3300 \mathrm{~mm}$ とし、ラミナ厚さは $30 \mathrm{~mm}$ とした。ラミナ は、JAS に準じて、弾性係数に基づき選別した。105 ${ }^{\circ} \mathrm{C}$ 乾燥前後の 重量を測定した結果より、Table 2 には樹種および断面寸法ごとに ラミナの全乾密度と含水率の平均值と最大・最小の值を示している。 一つの樹種・断面でのラミナサンプル数を 10 とし、サンプルは各 試験体の両端木口面から採取した。木材工業ハンドブック 7)による と、カラマツの気乾密度は平均 $0.50 \mathrm{~g} / \mathrm{cml}^{3}$ (最小 0.40 最大 $0.60 \mathrm{~g} / \mathrm{cml}^{3}$ ) とある。本実験に用いたカラマツ柱での気乾密度は平均 0.580 と $0.589 \mathrm{~g} / \mathrm{cm}^{3}$ で、一般的なものよりも高い值となった。接着剤にはレゾ ルシノール・フェノール樹脂系接着剂を用いた。Fig. 1 に試験体の断 面温度測定位置を示す。温度測定位置は、両樹種で同じとした。 $300 \mathrm{~mm}$ 角では 60 分加熱に対して、 $450 \mathrm{~mm}$ 角では 90 分加熱に対 して炭化領域と非炭化領域の境界部の温度および非炭化領域の温度 分布を把握できるような位置に熱電対を 15 箇所挿入した。 $300 \mathrm{~mm}$ 角試験体では $75 \mathrm{~mm} \times 300 \mathrm{~mm}$ の集成材を 4 つ、 $450 \mathrm{~mm}$ 角試験体で は $75 \mathrm{~mm} \times 450 \mathrm{~mm}$ と $150 \mathrm{~mm} \times 450 \mathrm{~mm}$ の集成材を 2 つずつ二次接 着し作成した。

\section{2 実験方法}

載荷加熱試験装置を Fig. 2 及び Photo 1 に示す。本実験は建材試 験センターの柱炉を用いて実施した。試験体上下端部に球座を設置 し、両端部ともに境界条件はピンとした。柱の座屈長さは $3,300 \mathrm{~mm}$ 、 加熱長さは 3,000mm とした。加熱条件はISO834-18) に規定される 標準加熱温度曲線に則り、設定した加熱時間で加熱した後、試験体 の荷重支持能力が喪失するまで、炉扉を閉じた状態での放冷を行っ た。Fig. 3 に炉内温度データの平均值の推移を示す。加熱時間 60 分 の場合で比較すると、放冷過程の温度は断面が大きいほど高くなっ た。またカラマツに比べスギの温度は高く推移した。本実験は不燃 材料で区画化された状況を再現したものである。実火災では、区画 部材の仕様や開口条件などにより, 火災減衰期の温度が実験時の炉 内温度よりも高くなる可能性がある。試験開始から 12 時間荷重を 支持し続けた試験体については、荷重を漸増させて破壊させ、破壊 性状を把握すると共に、12 時間時点での耐力を測定した。耐火性能 評価試験時と同様に放冷時の炉内の給気は、最小送風量を $6 \mathrm{~m}^{3} / \mathrm{min}$ とし、炉外との差圧がゼロになるように排気した。柱脚部の油圧ジ ヤッキにより試験体に載荷し、容量が $5 \mathrm{MN}$ のロードセルにて荷重 を制御した。柱脚側の球座の下部板（回転しない側）に変位計を二 箇所設置し、柱脚部の鉛直変位を測定し、その平均值を軸方向変位 とした。また柱脚側の球座上部板（回転する側）の鉛直変位を北東・ 南西・北西・南東の四䇢所で測定し、これらの相対変位を測定区間 の距離で除して柱脚部の回転角とした。球座上部板での鉛直変位は、 上部板の側面のボルト穴にアイボルトを取付け、球座と連動して動 くアイボルトの変位量を巻込み式変位計で測定した。本実験での破 壊時間は、収縮速度の急増により載荷荷重が試験荷重の $95 \%$ を下回 った時、もしくは収縮量が $33 \mathrm{~mm}$ (試験体長さの $1 / 100$ )に達した時 とした。加熱実験終了後の残存断面の計測は、破壊位置から長さ方 向に $\pm 300 \mathrm{~mm}$ と $\pm 900 \mathrm{~mm}$ の位置で切断した 4 断面を対象とし、柱 幅方向と柱背方向に関して $15 \mathrm{~mm}$ 間隔でノギスまたは定規にて計 測した。ただし、破壊位置が柱の中央付近以外で生じて、切断面が 


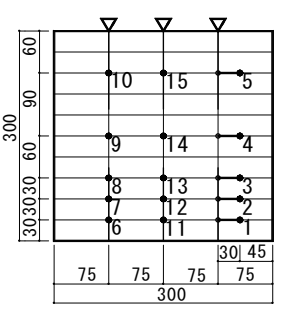

(a) $300 \times 300 \mathrm{~mm}$

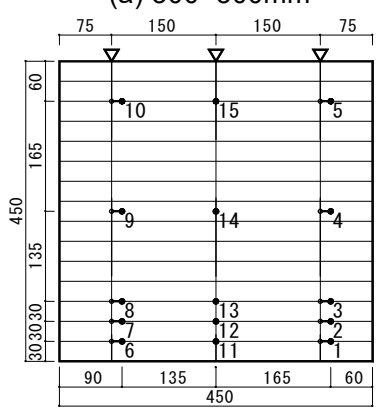

(b) $450 \times 450 \mathrm{~mm}$

- thermocouple $\nabla$ assembly glue

Fig. 1 Cross-sections and position of thermocouples

Table 3 Test results

\begin{tabular}{|l|c|c|c|c|c|c|}
\hline $\begin{array}{c}\text { Specimen } \\
\text { name }\end{array}$ & $\begin{array}{c}\text { Failure } \\
\text { Time } \\
\text { [min] }\end{array}$ & $\begin{array}{c}\text { Failure } \\
\text { mode* }\end{array}$ & $\begin{array}{c}\text { Load } \\
\text { bearing } \\
\text { capacity } \\
\text { [kN](Load) }\end{array}$ & $\begin{array}{c}\text { Residual } \\
\text { ratio in } \\
\text { cross- } \\
\text { sectional } \\
\text { area [\%] }\end{array}$ & $\begin{array}{c}\text { Residual ratio } \\
\text { in cross- } \\
\text { sectional } \\
\text { secondary } \\
\text { moment [\%] }\end{array}$ & $\begin{array}{c}\text { Slender- } \\
\text { ness } \\
\text { ratio }\end{array}$ \\
\hline \hline L300-30-1 & 257 & C & 788.4 & 61.4 & 35.1 & 50.4 \\
\hline L300-30-2/3 & 720 & B & $(1662.4)$ & 61.7 & 35.3 & 50.4 \\
\hline L300-60-1 & 95 & B & 788.4 & 41.8 & 16.0 & 61.7 \\
\hline L300-60-2/3 & 169 & B & 525.6 & 41.4 & 15.4 & 62.6 \\
\hline L300-60-1/3 & 720 & B & $(379.5)$ & 33.4 & 10.6 & 67.7 \\
\hline L450-60-1 & 283 & C & 1929.8 & 50.0 & 22.9 & 37.5 \\
\hline L450-60-1/3 & 720 & C & $(1014.9)$ & 44.5 & 18.1 & 39.8 \\
\hline L450-90-1 & 185 & B & 1929.8 & 40.6 & 15.4 & 41.2 \\
\hline L450-90-2/3 & 281 & B & 1286.5 & 33.8 & 10.4 & 45.7 \\
\hline L450-90-1/3 & 532 & B & 643.3 & 30.8 & 8.6 & 48.1 \\
\hline C300-30-1 & 120 & B & 624.6 & 59.4 & 33.2 & 51.0 \\
\hline C300-30-2/3 & 169 & B & 416.4 & 56.8 & 29.9 & 52.5 \\
\hline C300-60-1 & 66 & B & 624.6 & 37.7 & 13.2 & 64.5 \\
\hline C300-60-2/3 & 95 & B & 416.4 & 36.3 & 12.0 & 66.2 \\
\hline C300-60-1/3 & 158 & B & 208.2 & 31.5 & 9.2 & 70.6 \\
\hline C450-60-1 & 164 & B & 1528.9 & 47.2 & 20.9 & 38.2 \\
\hline C450-60-1/3 & 465 & C & 509.6 & 30.5 & 8.6 & 47.7 \\
\hline C450-90-1 & 125 & C & 1528.9 & 36.9 & 12.9 & 43.0 \\
\hline C450-90-2/3 & 166 & B & 1019.3 & 28.4 & 7.5 & 49.5 \\
\hline C450-90-1/3 & 320 & B & 509.6 & 30.4 & 8.5 & 48.2 \\
\hline
\end{tabular}

* B: Buckling C: Crushing

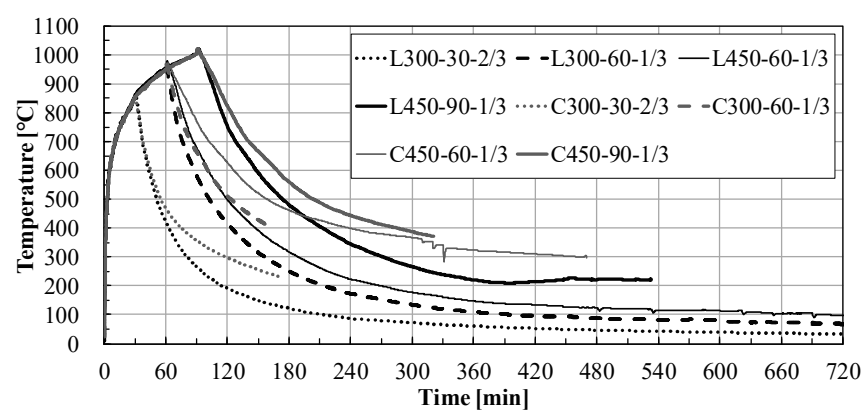

Fig. 3 Temperature in furnace

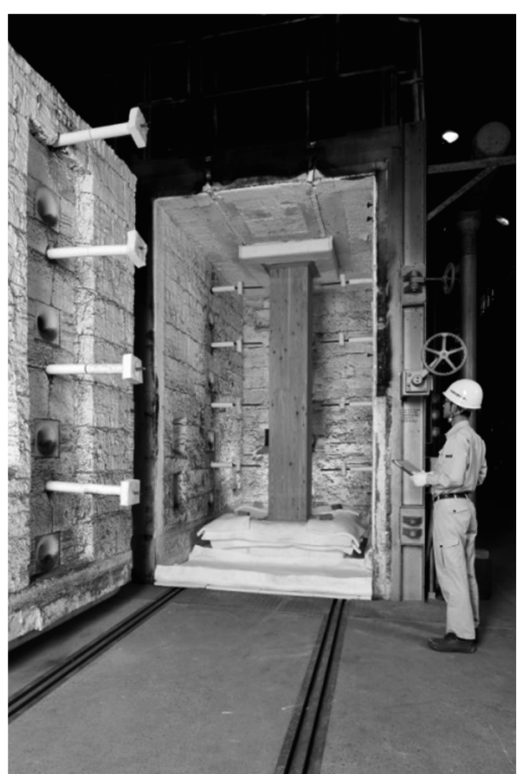

Photo 1 Exterior of a specimen and testing set

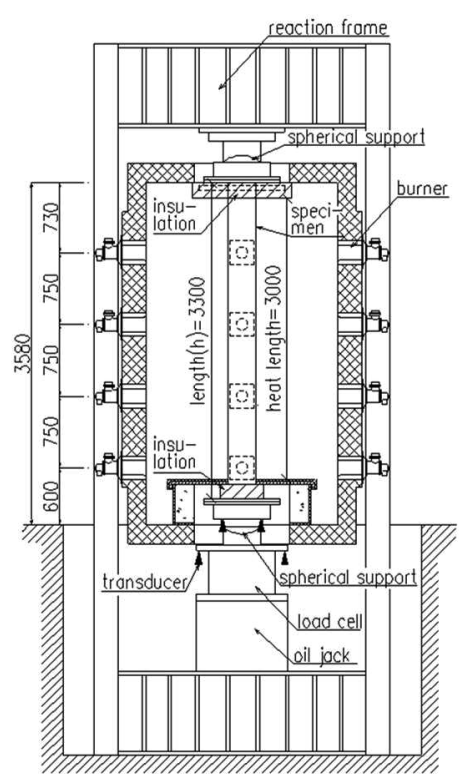

Fig. 2 Test setup
加熱範囲から外れた場合は、代わりに加熱範囲でもう 1 断面の残存 断面を計測した。

\section{3. 載荷加熱実験結果}

\section{1 破壊時間 - 炭化性状 - 破壊性状}

Table 3 に実験結果の概要として、破壊時間とその時間での荷重 または耐力、破壊形式、非炭化領域の断面積と断面二次モーメント の残存率、残存断面から求めた細長比を示す。12 時間(720 分)荷重 を支持した試験体に関しては、12 時間後に荷重を漸増させて得られ た最大荷重を耐力とした。C450-60-1/3と C450-90-1/3に関しては、 軸方向収縮量が ISO834-1 の規定值である $33 \mathrm{~mm}$ に達した時、その 他 18 体の試験体では、載荷荷重が試験荷重の 95\%を下回った時を 破壊時間とした。断面積および断面二次モーメントは、残存断面の 計測結果を用い、柱背 $15 \mathrm{~mm}$ 毎に得た残存断面幅による台形断面の 足し合わせとしてそれぞれ算出した。計測対象である 4 断面とも柱 幅方向と柱背方向の平均を取り、さらにその 4 断面の平均の值とし た。

Table 3 に示すように、全ての試験体において、加熱時間中に破 壊したものはなく、準耐火性能を満たすことを確認した。カラマツ 柱で 450 角の場合は、60 分加熱で荷重比 1 においても、加熱開始か ら 240 分以上荷重を支持し続ける性能を示した。カラマツ柱の 30 分加熱と 60 分加熱では、12 時間荷重を保持したものが 3 体あり、 30 分加熱の実験では燃え止まり性能も確認された。スギ柱に比べて 絶乾密度が大きなカラマツ柱の方が、同条件下で比較して、破壊時 間は長かった。断面が大きく、加熱時間が短く、荷重比が小さいほ ど破壊時間は長くなり、逆転現象は起こらなかった。

非炭化領域の断面積と断面二次モーメントの残存率を比較する と、断面二次モーメントの方がかなり小さく、火災時に柱がより座 屈しやすくなることが示された。同条件で同程度の破壊時間となっ たカラマツ柱(L300-60-2/3, 破壊時間 169 分)とスギ柱(C300-60-1/3, 破壊時間 158 分)の残存断面積はスギ柱の方が約 $10 \%$ 小さく、スギ 柱の方がカラマツ柱と比較すると炭化しやすい傾向が確認された。 


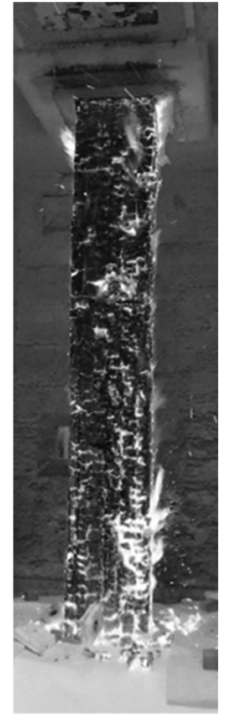

(a) $\mathrm{C} 450-90-1$

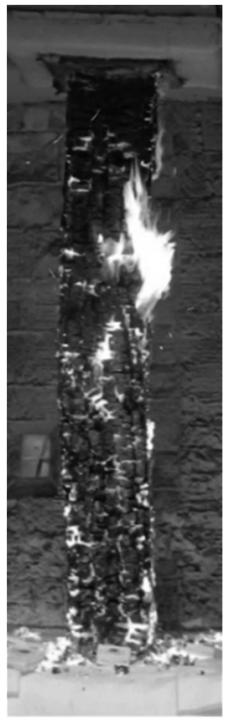

(b) $\mathrm{C} 450-90-2 / 3$ (Buckling)

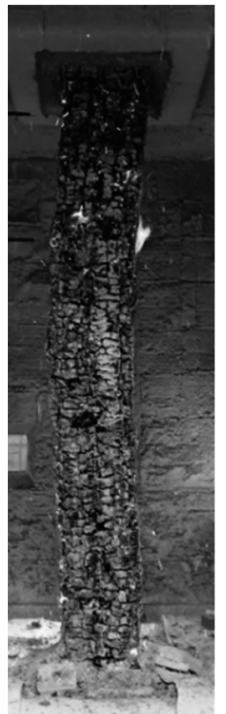

(c) C450-90-1/3 (Buckling) Photo 2 Deformation and failure

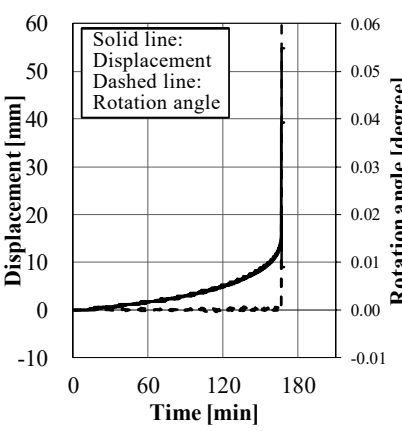

(a) C-450-90-2/3

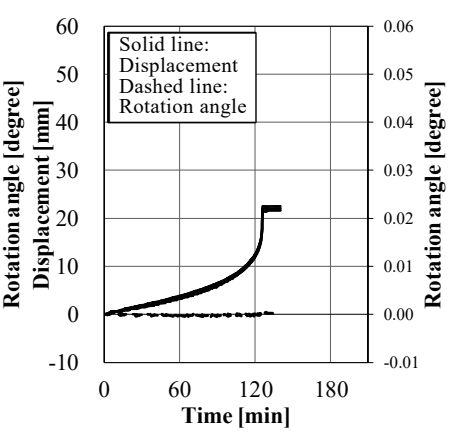

(b) C-450-90-1
Fig. 4 Displacement and Rotation angle of spherical support

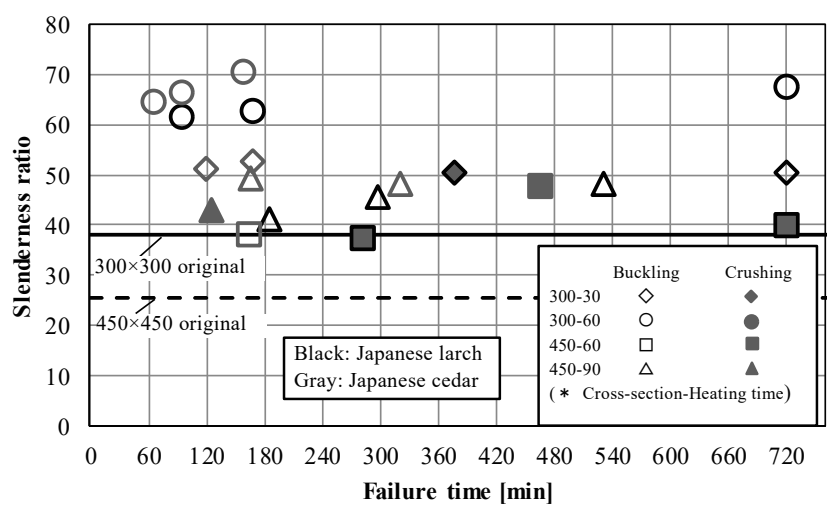

Fig. 5 Slenderness ratio-failure time relationship

同じ加熱時間で荷重比が異なるカラマツ柱の L300-60-1 と L30060-1/3 を比較すると、いずれも加熱終了後に破壊したにも関わらず、 残存断面積の割合で約 1.25 倍の差が見られ、加熱終了後の放冷過程 において炭化が進行したことが確認された。この傾向はスギ柱でも 同様であった。

破壊性状について、本実験においては、試験体の破壊状況に加え、 球座の回転状況により、試験体全体が屈曲寸る座屈破壊と、局所的 に潰れる圧壊の二種類に分類した。実験終了時の変形及び破壊性状 の例を Photo 2 に示寸。柱脚部の鉛直変位及び球座回転角の推移に
ついて、座屈破壊した場合の例を Fig. 4 の(a)に、圧壊した場合の例 をFig. 4 の(b)に示寸。球座の回転角は、球座における北東と南西の 鉛直変位の差および北西と南東の差を、各両者の距離で除したもの である。Fig. 4 の(a)に示す座屈破壊の例では、鉛直変位が増大寸る 破壊時に回転角の発生と急増が見られるが、Fig. 4 の(b)に示寸圧壊 の場合はそれが見られない。全 20 体の試験体の内、15 体が座屈破 壊であった。座屈破壊が多い理由は、加熱時および放冷時に断面が 減少して細長比が大きくなったためである。Fig. 5 に実験終了後の 残存断面の計測結果を用いて算出した細長比と破壊時間の関係を示 す。本実験では、細長比が 51 を超える場合で、すべて座屈破壊とな った。450 角断面で 60 分加熱の場合は圧壊が多かったが、300 角断 面で 60 分加熱の場合はすべて座屈破壊であった。元断面が大きい と、破壊時の細長比も小さくなるため座屈しにくくなり、燃え込み が大きく残存断面積が小さな部分で圧壊したと考えられる。450 角 断面であっても 90 分加熱の場合は、座屈破壊が多かった。元断面 が大きい場合でも、加熱時間が長くなると破壊時の細長比が大きく なり、座屈破壊へと移行する傾向が見られた。スギ柱はカラマツ柱 と比較し、短い時間で細長比が大きくなり、早期に座屈破壊する傾 向が見られた。

\section{2 断面内温度}

火災時における柱の耐力を算定する際は、非炭化領域の温度の把 握が重要となる。Fig. 6 の(a) (d)にカラマツ柱、Fig. 7 の(a) (d)に スギ柱における温度一時間関係の実験結果を示す。カラマツ柱の炭 化層の境界部に近い箇所の温度は、加熱終了から 3 時間位時間が経 過すると停滞して、その後に低下寸る傾向が見られた。一方、スギ 柱では、放冷過程においても、非炭化領域での温度が上昇し続ける 傾向が見られた。炭化温度を $260^{\circ} \mathrm{C}$ と仮定した場合、加熱中には炭 化に至らなくとも、放冷時に炭化したと思われる箇所がこれらの温 度結果から把握された。また同条件下では、カラマツ柱に比べてス ギ柱の方が、 $260^{\circ} \mathrm{C}$ を超えた箇所が多かった。カラマツ、スギともに

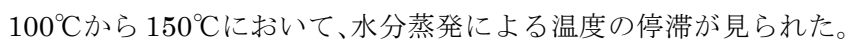

Fig. 6(b)のカラマツ柱 300 角・ 60 分加熱では断面中心部(No.14)が $100^{\circ} \mathrm{C}$ に到達した時間は試験開始から 270 分頃であったが、 450 角・ 60 分加熱では 720 分頃であった。断面の増加により、未炭化領域に おける温度上昇速度が大幅に低下寸ることが確認された。Fig. 7 の (c)において、No.11 から No.14 の温度が 135 分以降、その他の温度 が 225 分以降に急激に上昇した。これは被覆を施した柱脚部におい て燃え込みが発生し、熱電対が短絡したことが原因である。

Fig. 8 の(a)に 300 角, 60 分加熱、Fig. 8 の(b)に 450 角, 90 分加 熱試験体の断面内温度における樹種の違いによる影響を示す。Fig. 8(a)の 300 角・60 分加熱条件では、加熱中は非炭化領域の温度でカ ラマツとスギによる差はないが、加熱終了後はスギがカラマツの温 度を若干上回った。Fig. 8(b)の 450 角・90 分加熱条件では、初期温 度の差もあってか、加熱中からスギの方がカラマッよりも先に温度 が上昇して高い温度を保持し続けた。その他の実験条件でも、スギ の方がカラマツよりも温度が高くなる傾向が見られた。

\section{3 軸変形挙動}

Fig. 9(a) (d)に柱脚部での軸方向変位と時間の関係を示す。収縮 方向を正とし、以下ではこの軸方向変位を収縮量と称す。全試験体 において、収縮量の増加は加熱開始直後から始まった。収縮量は、 


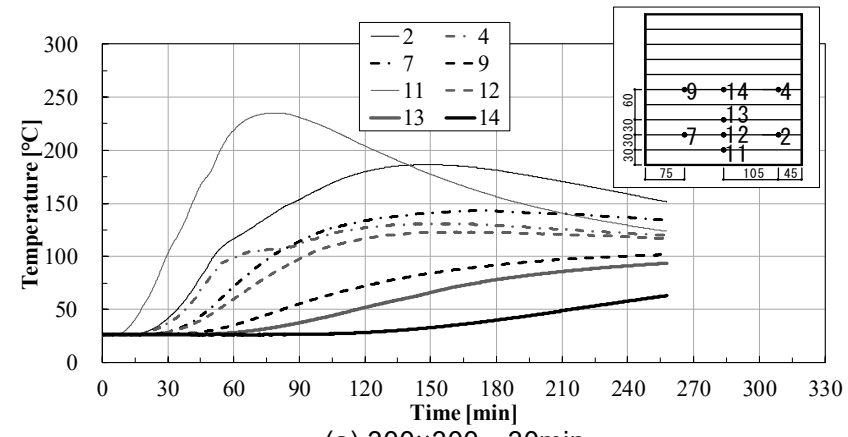

(a) $300 \times 300 \cdot 30 \mathrm{~min}$

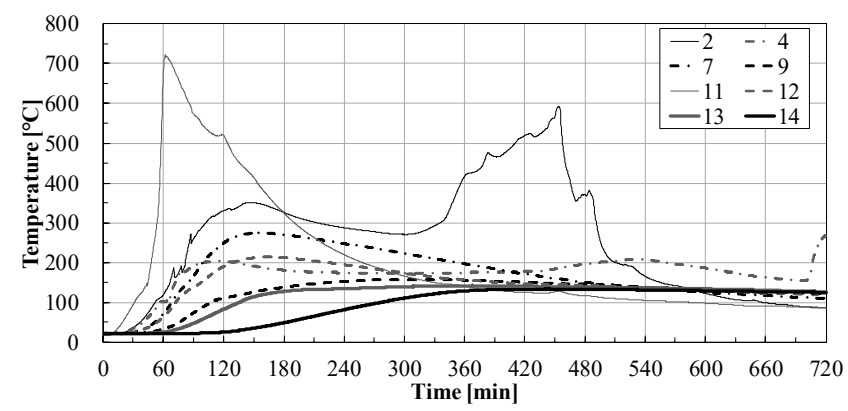

(b) $300 \times 300 \cdot 60 \mathrm{~min}$

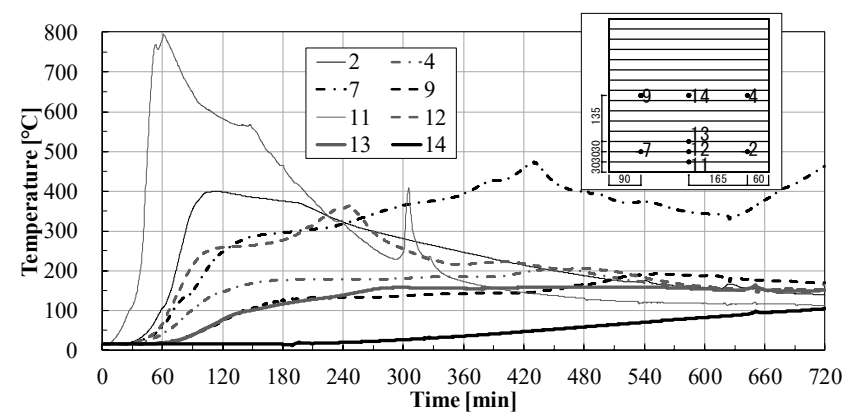

(c) $450 \times 450 \cdot 60 \mathrm{~min}$

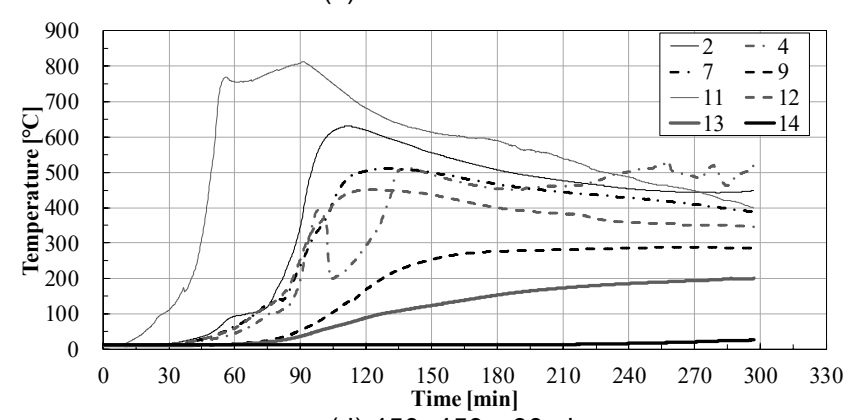

(d) $450 \times 450 \cdot 90 \mathrm{~min}$

Fig. 6 Cross-section temperatures of Japanese larch columns

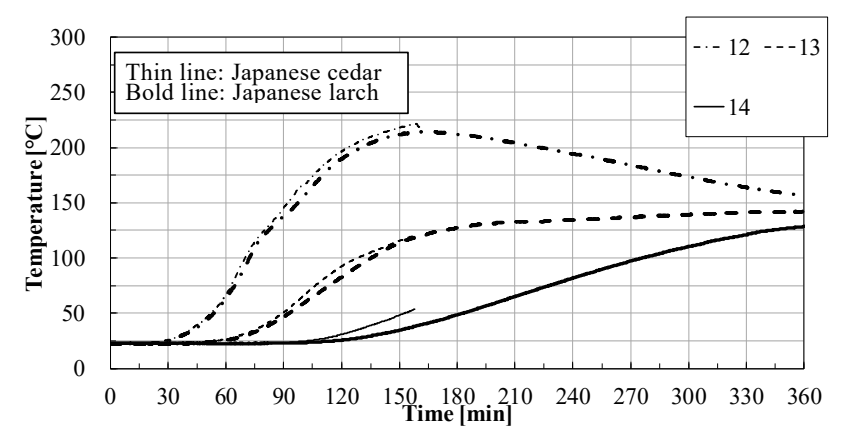

(a) $300 \times 300 \cdot 60 \mathrm{~min}$

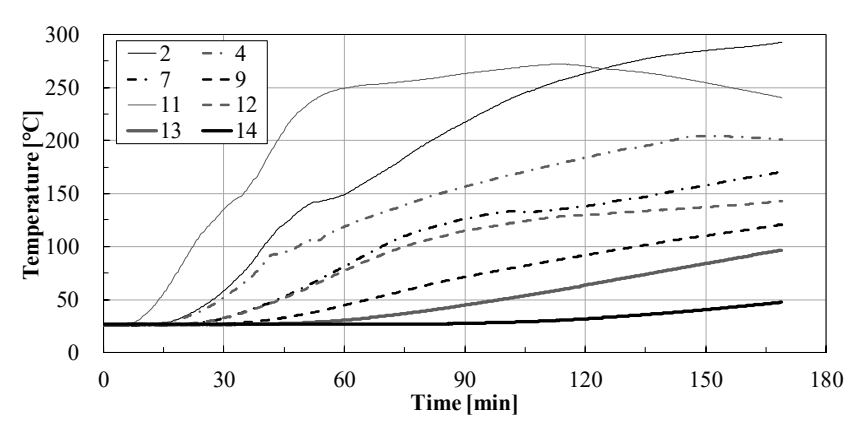

(a) $300 \times 300 \cdot 30 \mathrm{~min}$

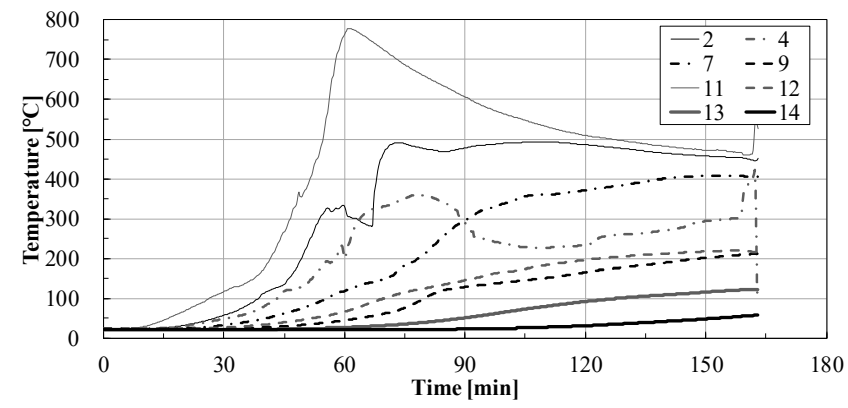

(b) $300 \times 300 \cdot 60 \mathrm{~min}$

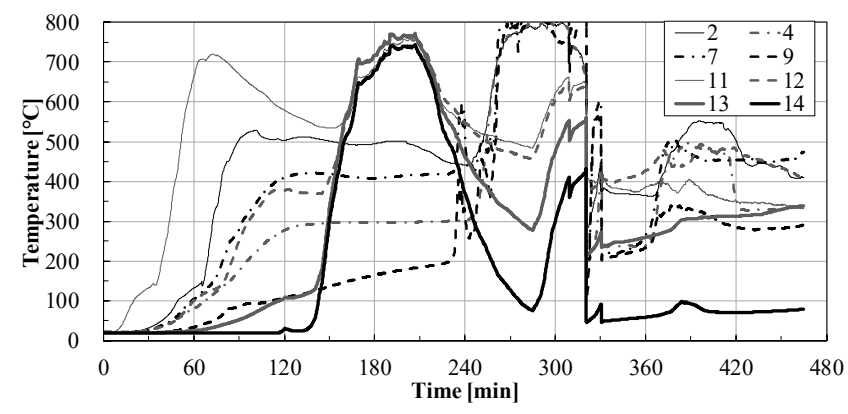

(c) $450 \times 450 \cdot 60 \mathrm{~min}$

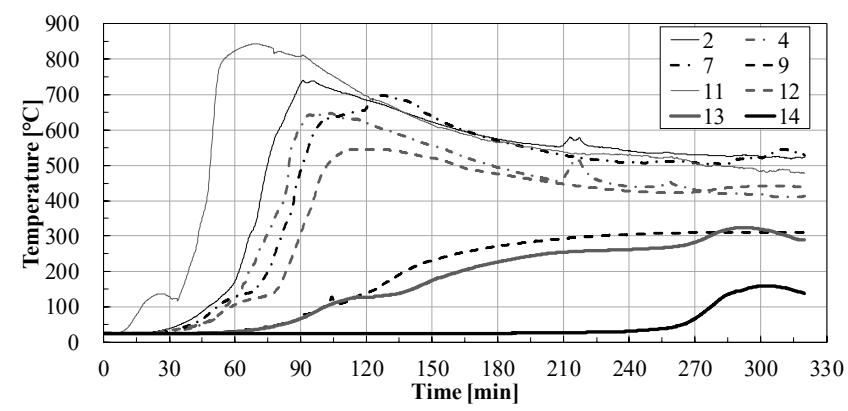

(d) $450 \times 450 \cdot 90 \mathrm{~min}$

Fig. 7 Cross-section temperatures of Japanese cedar columns

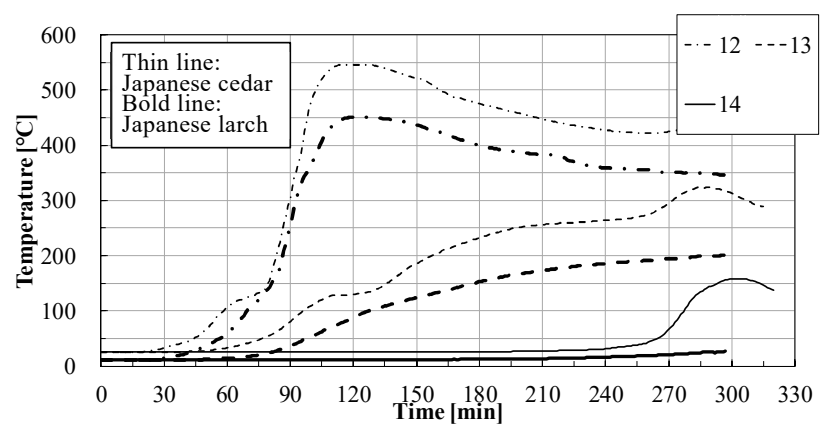

(b) $450 \times 450 \cdot 90 \mathrm{~min}$

Fig. 8 Effect of tree species 


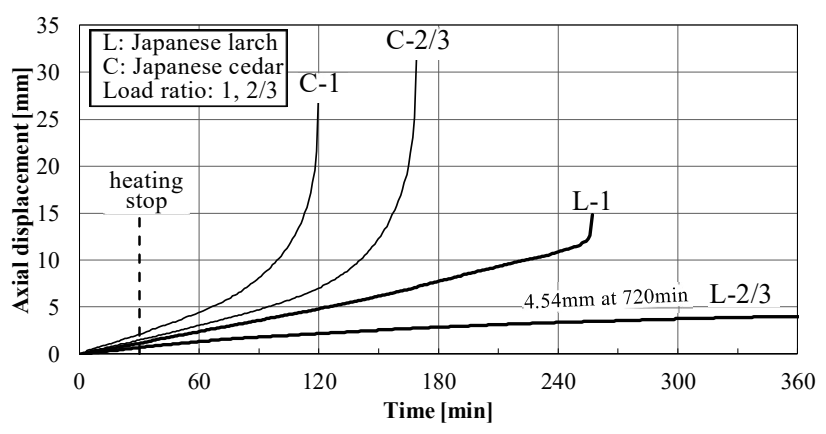

(a) $300 \times 300 \cdot 30 \mathrm{~min}$



(c) $450 \times 450 \cdot 60 \mathrm{~min}$

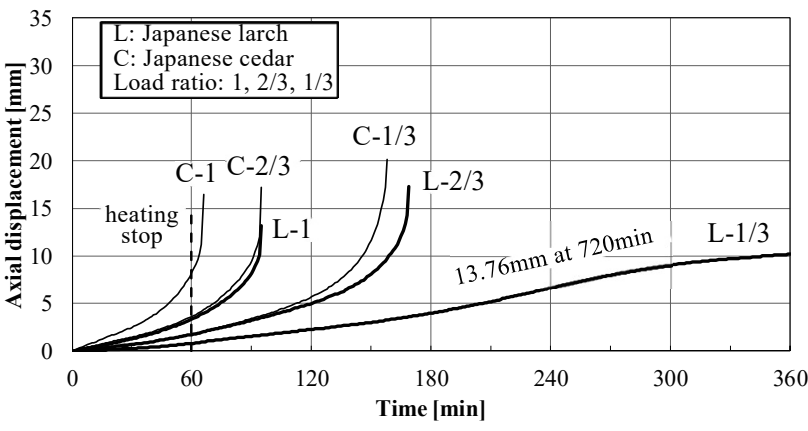

(b) $300 \times 300 \cdot 60 \mathrm{~min}$

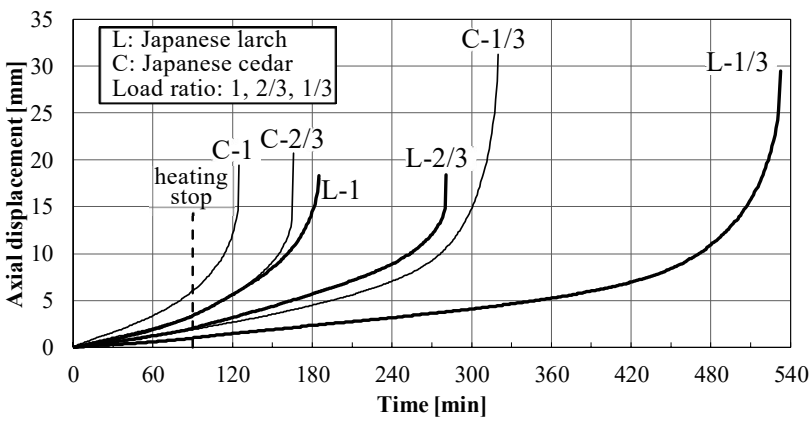

(d) $450 \times 450 \cdot 90 \mathrm{~min}$

Fig. 9 Axial displacement

加熱中よりも放冷過程においてより増加した。ISO834-18) では柱の 変形限界量を柱長さの $1 / 100$ (本実験では $33 \mathrm{~mm}$ ) と定めているが、2 例を除く試験体で収縮量が $33 \mathrm{~mm}$ に到達する前に破壊した。破壊時 の収縮量は柱長さの $1 / 200$ を上回るものが多く、スギでは全てで 1/200 を上回った。Fig. 9(a)で荷重比が異なる C- 1 と C-2/3 を比較 寸ると、加熱開始から荷重比 1 と比心荷重比 $2 / 3$ の収縮量の増加は 小さく、収縮量は荷重比と同程度の割合で増加した。破壊時間は荷 重比 1 の場合と比較し、荷重比 $2 / 3$ で約 1.4 倍となった。その他断 面・加熱条件下においても、同様の傾向が見られ、荷重比を小さく することで崩壊時間が大きく延びた。同断面・同荷重比の条件で、 加熱時間が異なる Fig. 9(c)の L-1(60 分加熱)と Fig. 9(d)の L-1(90 分加熱)を比較すると、90 分時点での収縮量は $3 \mathrm{~mm}$ 位で同程度だ が、その後は 90 分加熱の収縮速度が大きくなり、100 分位早く破壊 に至った。同加熱・同荷重比の条件 $(\mathrm{C}-1, \mathrm{~L}-1, \mathrm{C}-1 / 3, \mathrm{~L}-1 / 3)$ で、断面 が異なる Fig. 9(b) と Fig. 9(c)に示す結果を比較すると、300 角断面 に比べて 450 角断面の破壊時間はカラマツ・スギともに $2 \sim 3$ 倍であ った。元断面が大きいと非炭化領域の残存断面積の割合が大きく、 内部温度上昇も抑制されるため、破壊時間は大きく伸びた。樹種で 比較すると、加熱終了時点のスギ柱の収縮量はカラマツ柱の $1.5 \sim 2$ 倍程度であった。カラマツに比べてスギは燃焼しやすく、炭化の進 行に伴う断面減少も大きいため、早期に収縮量が増加して破壊に至 った。破壊時の収縮量の平均值は、カラマツが $17.8 \mathrm{~mm}$ 、スギが 25.8mm であり、スギはカラマツの 1.45 倍であった。Fig. 9(b)の L1/3 では、270 分位で収縮量の増加は小さくなり、結果として 720 分間荷重を保持し続けた。非炭化領域の温度が全域で $100^{\circ} \mathrm{C}$ を超え た 270 分位で収縮量の増加が小さくなった理由は、断面内部の水分

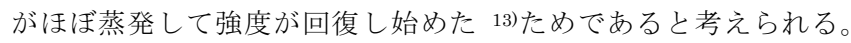
Fig. 9(d)の 90 分加熱においては、12 時間荷重を保持したものはな
かった。しかし L-1/3のように荷重を小さくすれば、90 分加熱にお いても 360 分以上荷重を支持できる可能性が示された。

\section{4. 柱の火災時座屈耐力および破壊時間に関する考察 4.1 火災時における柱の座屈耐力の計算方法}

火災加熱を受ける構造用集成材柱の座屈耐力を接線係数理論に 基づき計算し、座屈耐力と載荷荷重が一致する時間を計算による破 壊時間とし、実験で得た破壊時間と比較した。この手法は、本会の 鋼構造耐火指針 9) およびコンクリート充填鋼管構造設計施工指針 10)にて採用されている方法である。木材の熱膨張ひずみは比較的小 さいため本耐力計算においては無視した。

柱の圧縮ひずみを $\varepsilon$ とすると、そのひずみに対応する要素 $i$ の応 力 $\sigma_{i}$ を合算して得る柱の圧縮力 $N_{1}$ は下の式(1)で与えられる。断面内 の位置で要素毎の温度が異なるため、ひずみは同じでも各要素の応 力は異なる。

$$
N_{1}=\sum_{i}\left\{\sigma_{i} \cdot A_{i}\right\}
$$

ここで、 $\sigma_{i}$ : 要素 $i$ の応力-ひずみ曲線上でひずみ $\mathcal{E}$ 時の応力 $\left[\mathrm{N} / \mathrm{mm}^{2}\right]$ $A_{i}:$ 要素 $i$ の断面積 $\left[\mathrm{mm}^{2}\right]$ (以下同じ) そのひずみ $\mathcal{E}$ に対応する接線係数を $E_{t, i}$ とすると、そのときの柱の座 屈荷重 $N_{2}$ を下の式(2)で与えられる。

$$
N_{2}=\sum_{i} \frac{\pi^{2} \cdot E_{t, i} \cdot A_{i} \cdot y_{i}^{2}}{l^{2}}
$$

ここで、 $l:$ 柱の長さ, 有効座屈長さ $(3,300 \mathrm{~mm})$

$E_{t, i}$ : 要素 $i$ の応力-ひずみ曲線上でひずみ $\mathcal{E}$ の接線係数 $\left[\mathrm{N} / \mathrm{mm}^{2}\right]$ $y_{i}$ : 断面の図心軸から要素 $i$ の図心までの距離 $[\mathrm{mm}]$ 本計算では要素数を 300 角断面で 576 要素、450 角断面で 1156 要 素に分割しているため、断面図心軸に関する二次モーメントを $A_{i}$. 
$y_{i}{ }^{2}$ で近似した。式(1)より得る圧縮力 $N_{1}$ と式(2)により得る座屈荷重 $N_{2}$ が同值となるときの值をその時間における柱の座屈耐力 $P_{c r}$ とし た。そして、この座屈耐力と載荷荷重が等しくなる時間を柱の破壊 時間とした。

なお柱の断面耐力 $P_{u}$ は下の式(3)で求めた。

$$
P_{u}=\sum_{i} \sigma_{c, i} \cdot A_{i}
$$

\section{ここで、 $\sigma_{c, i}:$ 要素 $i$ の圧縮強度 $\left[\mathrm{N} / \mathrm{mm}^{2}\right]$}

Fig. 10 に座屈耐力 $P_{c r}$ と断面耐力 $P_{u}$ の例として、カラマツ柱・ $300 \mathrm{~mm}$ 角・60 分加熱での 60 分時の結果を示す。本計算はひずみ を $10 \times 10^{-6}$ ごとに増加させて算出した。Fig. 10 に示すように $N_{1}$ と $N_{2}$ の交点より $P_{c r}$ が得られ、 $N_{1}$ は $P_{u}$ に漸近する。Fig. 11 の(a) と(b)に カラマツおよびスギの圧縮に関する高温時応力ーひずみ曲線を示す。 応力 $\sigma$ ひずみ $\varepsilon$ 曲線は、Richard 式 11)を参照して下式で与えた。

$$
\begin{gathered}
\sigma=\frac{\left(E-E_{p}\right) \cdot \varepsilon}{\left\{1+\left|\frac{\varepsilon}{\varepsilon_{1}}\right|^{n}\right\}^{\frac{1}{n}}} \\
\varepsilon_{1}=\frac{\sigma_{c}-0.01 E_{p}}{E-E_{p}}
\end{gathered}
$$

ここで、 $E$ : 圧縮弾性係数 $\left[\mathrm{N} / \mathrm{mm}^{2}\right], E_{p}$ : 硬化係数 $\left(E_{p}=E / 1000\right)$

$\varepsilon_{1}:$ 漸近線の交点におけるひずみ, $\sigma_{c}$ : 圧縮強度 $\left[\mathrm{N} / \mathrm{mm}^{2}\right]$

$n$ :応力-ひずみ曲線のとがり具合を表す係数 $(n=4.0), T$ : 温度 $\left[{ }^{\circ} \mathrm{C}\right]$ 上式における力学的特性には高温時の值を用いる。カラマツとスギ の高温時における圧縮強度と圧縮弾性係数は、Eurocode5 ${ }^{12)}$ の付録 に示されている softwood の高温時残存率に常温值を乗じて与えた。 Eurocode 5 では、圧縮強度を $100^{\circ} \mathrm{C}$ で常温時の $25 \%$ 、圧縮弹性係数 を $100^{\circ} \mathrm{C}$ で常温時の $35 \%$ とし、 $300^{\circ} \mathrm{C}$ で両者の值をゼロとし、その

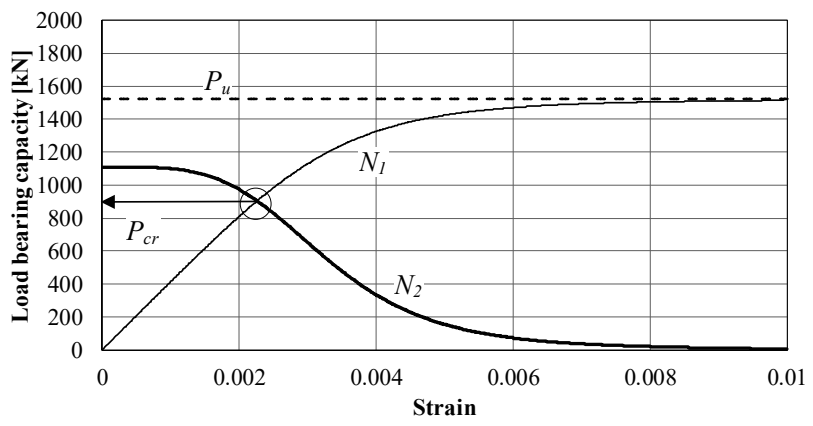

Fig. 10 An example of $P_{c r}$ and $P_{u}$ at $60 \mathrm{~min}(\mathrm{~L}-300-60)$

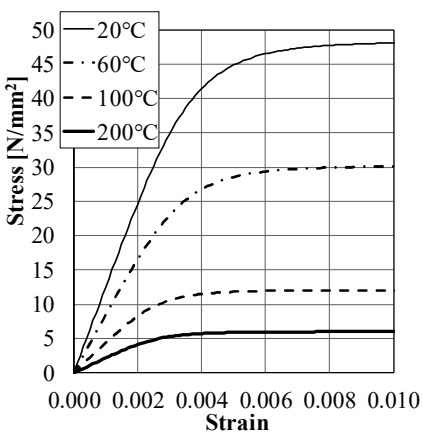

(a) Japanese larch

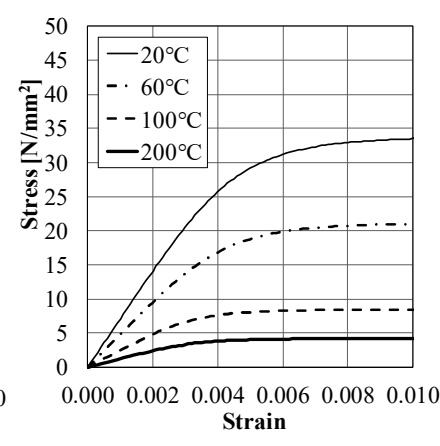

(b) Japanese cedar Fig. 11 Compressive stress-strain curves

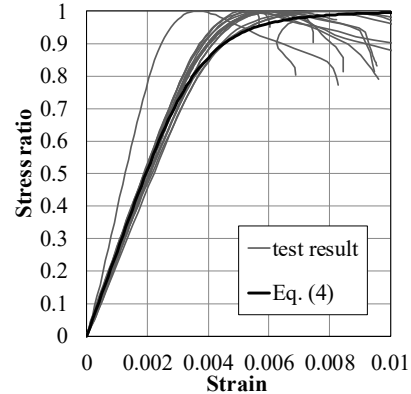

(a) Japanese larch at $20^{\circ} \mathrm{C}$

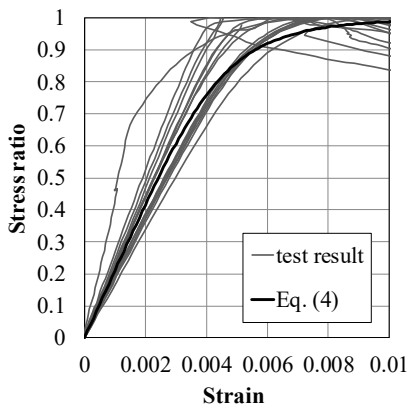

(c) Japanese cedar at $20^{\circ} \mathrm{C}$

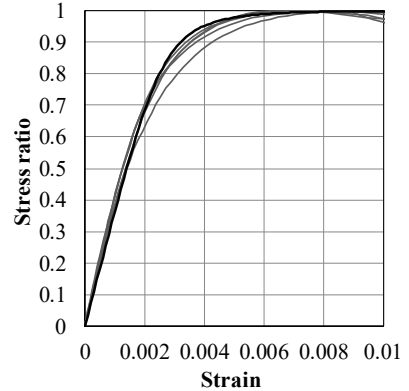

(b) Japanese larch at $100^{\circ} \mathrm{C}$

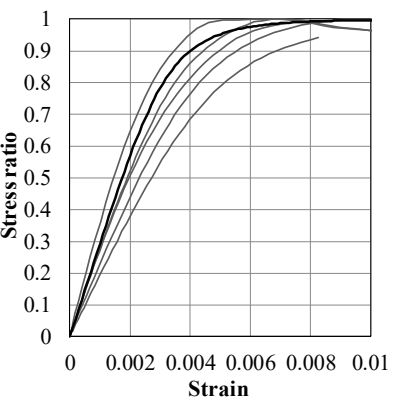

(d) Japanese cedar at $100^{\circ} \mathrm{C}$
Fig. 12 Relation between stress ratio and strain

間を線形補間している。常温時の圧縮強度と圧縮弾性係数は、素材 の圧縮実験結果 13) に基づき、カラマツでは $48.5 \mathrm{~N} / \mathrm{mm}^{2}$ と 12,563 $\mathrm{N} / \mathrm{mm}^{2}$ 、スギでは $34.0 \mathrm{~N} / \mathrm{mm}^{2}$ と $7,109 \mathrm{~N} / \mathrm{mm}^{2}$ とした。耐力計算に 用いた温度は、各要素が経験した最高履歷温度とした。Fig. 12 に素 材の高温時圧縮実験結果 13)から得た応力比-ひずみ関係と Richard 式に基づく式(4)の応力比-ひずみ関係を示す。応力比は各素材試験 体のその時点のひずみでの応力を最大応力で割った值である。式(4) の $n$ の值を 4.0 とすると、両樹種共に常温と $100^{\circ} \mathrm{C}$ に応力比-ひず み曲線が概㸚対応した。

\section{2 柱の断面内温度分布}

火災時耐力を計算する際は、木材の高温時における弾性係数と強 度の低下を考慮するため、断面内温度を正確に与える必要がある。 木材の場合、断面内温度測定点の燃え込みの状況などに影響し、同 じ測定位置であっても温度のばらつきが見られる。また実験で得ら れる温度情報は Fig. 1 で示したように限定的である。したがって、 耐力計算に用いる断面内温度分布は、実験で得た温度の結果ではな く、2 次元有限要素法による熱伝導解析 14) により与えた。その熱伝 導解析に用いる熱定数は、実験で得られた温度結果に対応するよう 設定した。常温時の絶乾密度および重量含水率は、Table 2 に示し たサンプル值を使用した。高温時の木材の熱特性(密度・比熱・熱伝 導率)は Eurocode5 に基づき設定したが、カラマツの熱伝導率のみ 実験結果に合わせるよう Eurocode5 の值の 1.35 倍に設定した ${ }^{15)}$ 。 加熱終了後の放冷過程において、木材自身による発熱を考慮するた め、自己燃焼効率を定めた。自己燃焼効率は、木材の全発熱量に対 して要素の温度上昇に寄与寸る熱量の割合であり、炭化層との境界 部近傍における温度の実験結果と近い值になるよう設定した ${ }^{14)}$, 15)。 断面内の要素分割は、300 角断面では各辺を 24 分割し 576 要素、 450 角断面では各辺を 34 分割し 1156 要素とした。要素の幅は、温 度変化が急である表面付近を $7.5 \mathrm{~mm}$ 、中心部で最大 $30 \mathrm{~mm}$ とし、 実験時の温度測定位置と対応するようにした。入力温度は、加熱時 
間中は ISO834-1 による標準加熱温度曲線とし、加熱終了後の放冷 過程の温度は、炉内温度の実験結果に基づき近似式で与えた。

実験結果と解析結果の比較の例として、300 角・60 分加熱条件に おけるカラマツの結果を Fig. 13(a)にスギの結果を Fig. 13(b)に示 す。実験より得た 15 点での温度について、耐力計算に関係する $300^{\circ} \mathrm{C}$ 以下の範囲で比較した。カラマツ、スギともに $150^{\circ} \mathrm{C}$ 超える 箇所の一部の温度で実験值と解析值に差が見られるが、非炭化領域 での温度は概ね $\pm 20 \%$ 範囲に収まった。Fig. 14 に両樹種における 300 角之 450 角の 60 分加熱条件の断面中心部(No.14) と炭化層境界 部近傍の温度(No.9)での実験值と解析值の比較を示す。炭化境界部 近傍での温度(No.9) は若干実験值と解析值に差があるが、圧縮強度 及び弾性係数が大きく低下寸る $100^{\circ} \mathrm{C}$ まて範囲内では断面中心部 (No.14)、炭化境界部近傍(No.9)共に精度よく追跡できた。火災時に おける木材の内部温度については、不燃材料であるコンクリートの 内部の温度などと比べても実験結果のばらつきが大きいため、これ 以上の精度で実験結果を再現することは難しいと判断した。

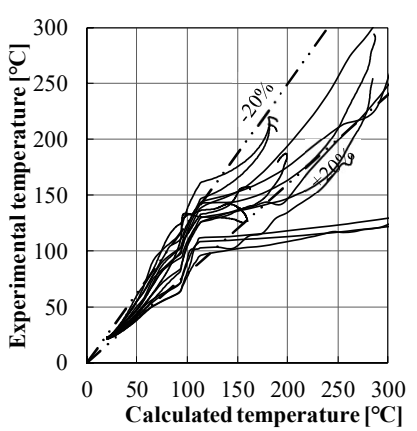

(a) Japanese larch

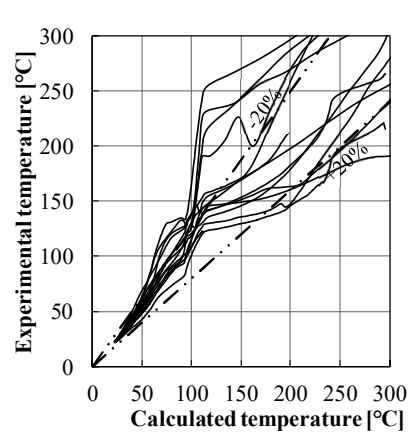

(b) Japanese cedar
Fig. 13 Comparison of temperature

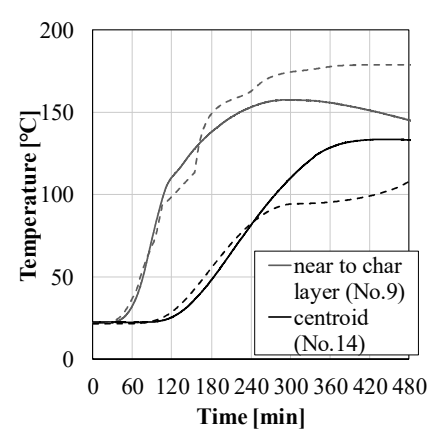

(a) L300

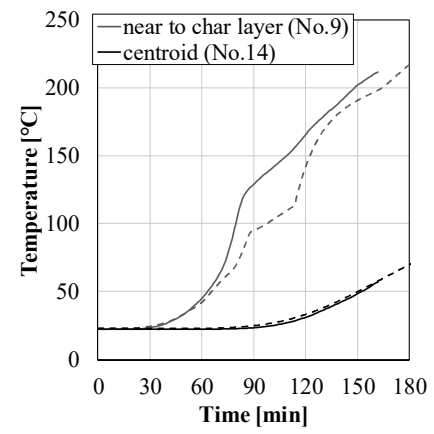

(c) $\mathrm{C} 300$

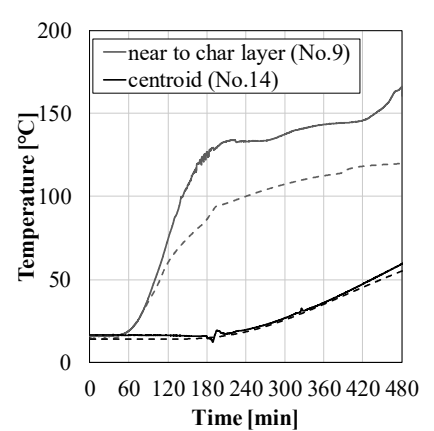

(b) $L 450$

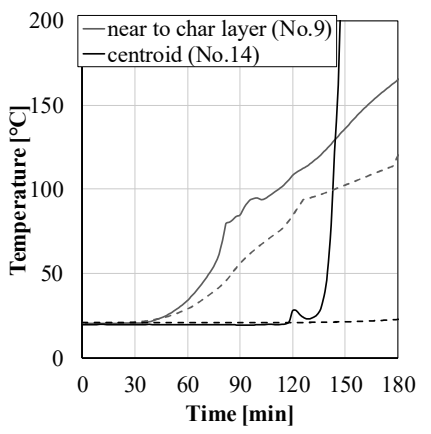

(d) $\mathrm{C} 450$
Fig. 14 Comparison of cross-section temperature between test and analysis results (Solid line: test, Dashed line: analysis)

\section{3 計算結果と実験結果の比較}

Fig. 15 に 300 角・ 60 分加熱 450 角・90 分加熱条件でのカラマ ツ柱およびスギ柱の座屈耐力 $P_{c r}$ と断面耐力 $P_{u}$ の計算結果を示す。耐 力計算の結果は 20 分ごとに出力した。プロットは各実験での破壊 時間を示している。座屈耐力および断面耐力の低下曲線と実験時の 載荷荷重を示した横線の交点が計算による破壊時間である。実験に よる破壊時間は、Fig. 15 に示寸例のように、座屈による破壊時間と 断面耐力に達する時間の間にあるものが大半であった。計算による 耐力低下曲線は、断面の大きさや加熱時間に関わらず、実験で得た 耐力の低下傾向を捉えていることが分かる。Fig. 15(b),(d)に示寸ス ギ柱では耐力低下が止まらずに耐力が 0 に近づいたが、Fig. 15(a),(c)に示すカラマツ柱では耐力低下が徐々に小さくなった。 $P_{c r}$ と $P_{u}$ を比較すると、 $P_{c r}$ の方が早い時間帯での耐力低下が大きい。こ

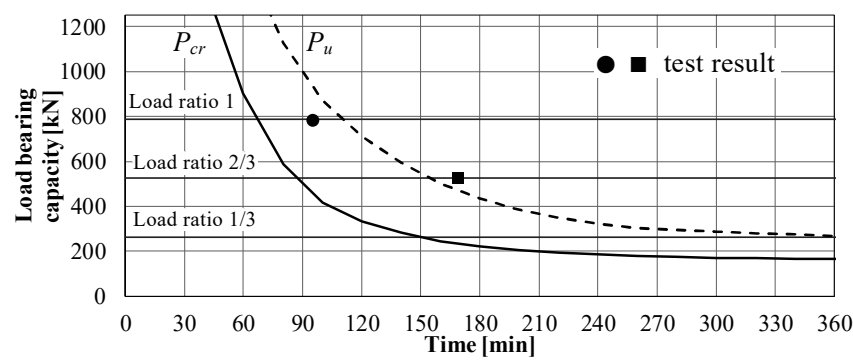

(a) Japanese larch $(300 \times 300,60 \mathrm{~min})$

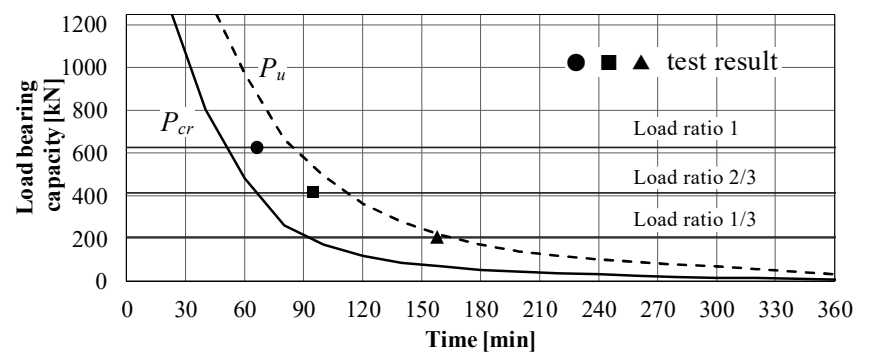

(b) Japanese cedar $(300 \times 300,60 \mathrm{~min})$

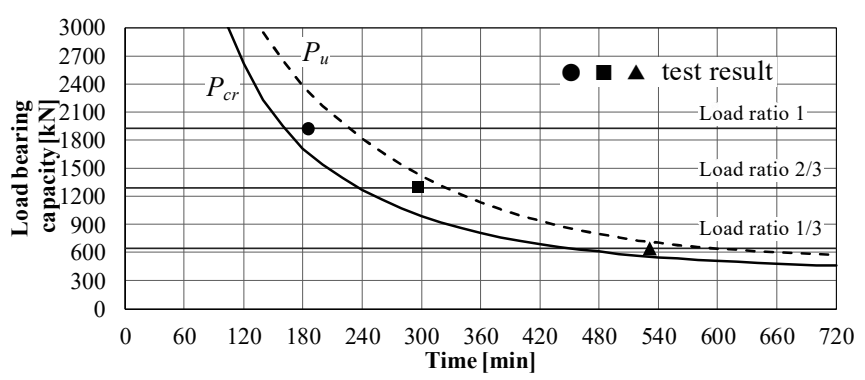

(c) Japanese larch $(450 \times 450,90 \mathrm{~min})$

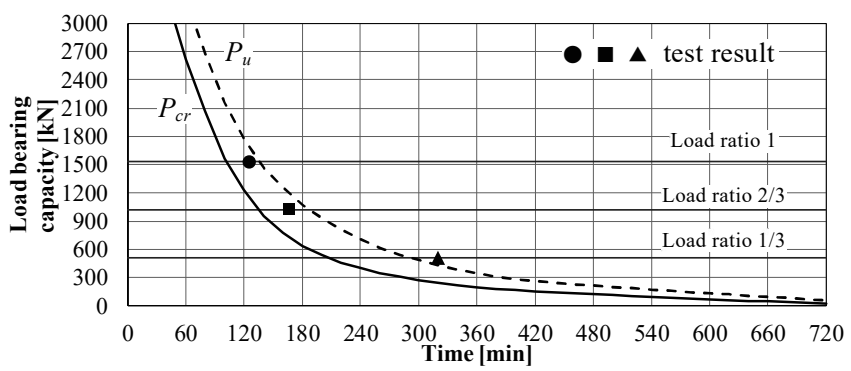

(d) Japanese cedar (450×450, 90min)

Fig. 15 Load bearing capacity-time relationship 
れは時間経過に伴う断面積の低下の度合いよりも断面二次モーメン トの低下の度合いが大きいことに起因する。また柱の細長比が大き な 300 角断面の方が $P_{c r}$ と $P_{u}$ の差は大きくなる。Fig. 16 に全 20 体 の実験の破壊時間と座屈耐力による破壊時間および断面耐力に到達 する時間の比較を示す。全ての条件で、座屈耐力による破壊時間は 実験の破壊時間よりも短かった。低荷重になるほど実験と座屈耐力 による破壊時間の差は大きくなった。断面耐力に達する破壊時間は 実験の破壊時間よりも長くなる傾向が見られた。以上の結果より、 カラマツ・スギの破壊時間は、Eurocode5 の高温時力学的特性を用 いた座屈耐力計算によって安全側に評価された。この理由は、本実 験に用いた木材の高温時強度・弾性係数が Eurocode 5 の設計值よ りも大きかったためと考えられる。

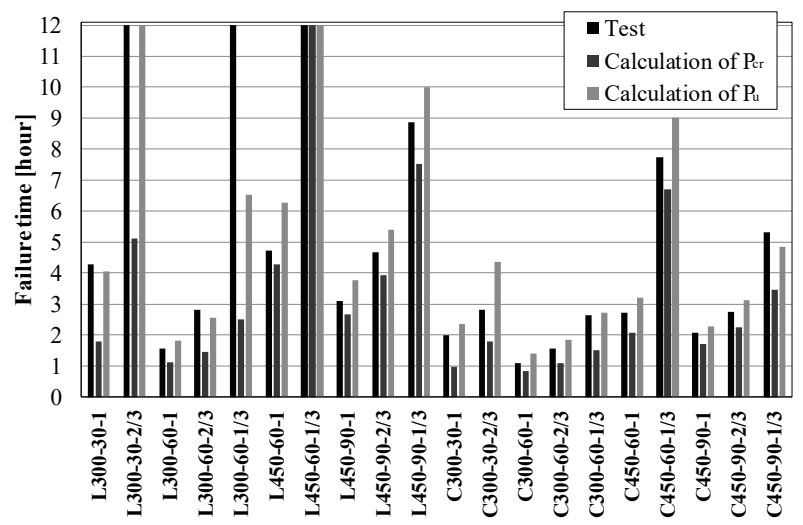

Fig. 16 Comparison of the failure times

\section{5. まとめ}

カラマツ・スギ構造用集成材による柱の載荷加熱実験を実施し、 樹種・断面寸法・加熱時間・荷重比による影響の違いを検討した。 また構造用集成材による柱の火災時座屈耐力に基づく破壊時間予測 方法を提案した。結果を以下にまとめる。

（1）カラマツ柱・スギ柱ともに、300 角断面では 60 分以上、 450 角 断面では 90 分以上の標準加熱に対して、長期許容荷重を加熱時 間以上支持した。カラマツ柱では、60 分加熱で荷重比が $1 / 3$ の とき 12 時間以上荷重を支持した。

（2）カラマツ柱に比べてスギ柱は、加熱終了後の断面減少が大きく、 また断面内部温度が高くなるため、早期に収縮量が増加して破 壊に至った。

（3）柱の破壊時の収縮量は柱長さの $1 / 200$ を上回るものが多かった。 カラマツ柱に比べ、スギ柱の方が破壊時の収縮量が大きかった。

（4）450 角断面の破壊時間は、同じ加熱時間と荷重比の 300 角断面 の破壊時間の $2 \sim 3$ 倍であった。

（5）本実験においては、破壊時の細長比が 51 を超えた試験体で、す べて座屈破壊となった。実験後の断面二次モーメントの残存率 は、断面積の残存率よりもかなり小さくなり、火災時に柱がよ り座屈しやすくなることを示した。

（6）接線係数理論および Eurocode5 の高温時力学的特性を用いた座 屈耐力計算による破壊時間は、全ての実験の破壊時間よりも短 く、カラマツ柱とスギ柱の破壊時間が安全側に評価された。
本論文においては Eurocode5 に基づいた高温時力学的特性值を与 えたが、この值をどう与えるかによって計算結果が大きく変化する。 高温時力学的特性值の適切な与え方についての更なる検討が必要で ある。

\section{謝辞}

本研究は、平成 28 年度〜平成 30 年度に国土交通省の住宅·建築 物技術高度化事業の助成を受け、千葉大学・日本集成材工業協同組 合・大成建設・日建設計の共同技術開発「構造用集成材を用いた建 築物の火災時倒壊時間予測に基づく設計技術の開発」の一部として 実施された。関係各位に謝意を表す。

\section{参考文献}

1) Architectural Institute of Japan: Standard for Structural Design of Timber Structures, 2006 (in Japanese) 日本建築学会 : 木質構造設計規準・同解説, 2006

2) H. Kinjo, S. Yusa, T. Horio, T. Hirashima, T. Matsumoto and K. Saito: Behaviours of Larch Glued Laminated Timber Beams Exposed to Standard Fire Heating During the Cooling Phase -Study on fire performance of structural glued laminated timber beams Part 1-, Journal of Structural and Construction Engineering (Transactions of AIJ), Vol. 80, No. 711, pp. 831-840, 2015. 5 (in Japanese) 金城仁，遊佐秀逸，堀尾岳成，平島岳夫，松本匠，齋藤潔：標準火災加熱を受 けたカラマツ集成材梁の放冷過程における挙動，構造用集成材梁の耐火性に関 する研究 その 1 , 日本建築学会構造系論文集 第 80 巻 第 711 号, pp. 831$840,2015.5$

3) Architectural Institute of Japan: Guide Book for Fire-Resistive Performance of Structural Materials, 2017 (in Japanese) 日本建築学会 : 構造材料の耐火性ガイドブック, 2017

4) K. Nakamura, K. Mogami: Fire Resistance Test of Glued Laminated Timber, Building Research Institute, Kenchiku Kenkyu Shiryo No.56, pp. 1-55, 1985. 12

中村賢一, 最上浤二: 構造用集成材の耐火性能実験, 建設省建築研究所 建 築研究資料 No.56, pp. 1-55, 1985. 12

5) N. Yasui, M. Shimizu, Y. Hasemi, M. Murakami, M. Kamijima, T. Kimura, A. Hokugo, Y. Tamura, M. Yoshida and K. Yamamoto: Prediction and Design of Mechanical Fire Resistance of Japanese Traditional Wood/Soil Walls by Compression Tests of Wood Posts, Journal of Environmental Engineering (Transactions of AIJ), No. 574, pp. 1-6, 2003. 12 (in Japanese)

安井昇, 清水真理子, 長谷見雄二, 村上雅英, 上島基英, 木村忠紀, 北後 明彦, 田村佳英, 吉田正友, 山本幸一: 柱圧縮試験による木造土壁の火㷋 加熱時の非損傷性予測と木造土壁外壁の防火設計, 日本建築学会環境系論 文集 第 574 号, pp. 1-6, 2013. 12

6) M. Shimizu, Y. Hasemi, M. Murakami and N. Yasui: Prediction of the Fire Resistance of Japanese Bare Timber Walls, Journal of Structural and Construction Engineering (Transactions of AIJ), No. 611, pp. 165170, 2007. 1 (in Japanese)

清水真理子, 長谷見雄二, 村上雅英, 安井昇 : 木造真壁の耐火性能予測, 日本建築学会構造系論文集 第 611 号, pp. 165-170, 2007. 1

7) Forestry and Forest Products Research Institute: Wood industry handbook, 2004. 3

森林総合研究所：木材工業ハンドブック, 2004.3 
8) ISO 834-1: Fire-resistance tests - Elements of building construction Part 1: General requirements, 1999

9) Architectural Institute of Japan: Recommendations for Fire Resistant Design of Steel Structures, 2017. 6 (in Japanese)

日本建築学会：鋼構造耐火設計指針, 2017. 6

10) Achitectural Institute of Japan: Recommendations for Design and Construction of Concrete Filled Steel Tubular Structures, 2008. 10 (in Japanese)

日本建築学会: コンクリート充填鋼管構造設計施工指針, 2008. 10

11) Richard, R.M., and Abbott. B.J. : Versatile elastic-plastic stress-strain formula, Journal of Engineering Mechanics, ASCE, Vol.10, No.4, pp. $511-515,1975$

12) Eurocode5: Design of timber structures - Part 1-2: General Structural fire design, 2004

13) M. Ichikawa, S. Baba, T. Kataoka, T. Someya, T. Hirashima: Mechanical Properties of Cedar and Lurch of Structural Glued Laminated Timber at High Temperature., Summaries of Technical Papers of Annual Meeting, Architectural Institute of Japan, Fire Safety, pp. 357-360, 2017. 7 (in Japanese)

市川萌都，馬場重彰，片岡辰幸，染谷朝幸，平島岳夫：高温加熱を受ける スギ・カラマツ構造用集成材の力学的特性, 日本建築学会大会学術講演梗 概集，防火, pp. 357-360, 2017.7

14) S. Ishii, M. Ichikawa, S. Baba, T. Kataoka, T. Someya and T. Hirashima: Sectional Temperature and Charring Behavior of Structural Glued Laminated Timber in Fire - Part 4. Heat Conduction Analysis Considering Self-Combustion of Timber - , Proceedings of JAFSE Annual Symposium 2018, JAFSE, pp. 92-93, 2018. 5 (in Japanese)

石井俊吾, 市川萌都, 馬場重彰, 片岡辰幸, 染谷朝幸, 平島岳夫：火災時 における構造用集成材の断面内温度と炭化性状-その 4 . 木材の自己燃焼を 考慮した伝熱解析-, 平成 30 年度日本火災学会研究発表会概要集, pp. 9293, 2018. 5

15) T. Igarashi, S. Ishii, S. Baba, K. Shimizu, T. Someya and T. Hirashima: Sectional Temperature and Charring Behavior of Structural Glued Laminated Timber in Fire - Part 7. Comparison of the test results and the heat conduction analysis results - , Proceedings of JAFSE Annual Symposium 2019, JAFSE, pp. 128-129, 2019. 5 (in Japanese)

五十嵐樹, 石井俊吾, 馬場重彰, 清水邦夫, 染谷朝幸, 平島岳夫：火災時 における構造用集成材の断面内温度と炭化性状-その 7. 実験結果と熱伝 導解析結果の比較-, 2019 年度日本火災学会研究発表会概要集, pp. 128129, 2019. 5 


\title{
BUCKLING STRENGTH AND FAILURE TIME OF JAPANESE
}

\section{CEDAR AND LARCH GLUED LAMINATED TIMBER COLUMNS EXPOSED TO FIRE}

\author{
Tatsuki IGARASHI*1, Shungo ISHII ${ }^{* 2}$, Heisuke YAMASHITA *3, \\ Shigeaki BABA *4, Tomoyuki SOMEYA*5 and Takeo HIRASHIMA*6 \\ ${ }^{* 1}$ Grad. Student, Graduate School of Sci. and Eng., Chiba Univ. \\ ${ }^{*}$ Kozo Keikaku Engineering Inc., M.Eng. (Former Grad. Student, Chiba Univ.) \\ *3 Japan Testing Center for Construction Materials, Dr.Eng. \\ *4 Taisei Advanced Center of Technology, Taisei Corporation, Dr.Eng. \\ ${ }^{*}$ Nikken Sekkei Ltd., Dr.Eng. \\ ${ }^{* 6}$ Prof., Graduate School of Engineering, Chiba Univ., Dr.Eng.
}

Timber elements have a problem in that the load bearing capacity decreases due to self-burning during cooling phase. In the case of timber columns exposed to fire, it is possible to fail with buckling because the cross-sectional secondary moment decrease considerably. Buckling failure of columns in fire may induce collapse of building, and it involve in the lives of fireman. However, there was a few load bearing fire test data to research the buckling behavior and failure time of the glued laminated timber columns exposed to fire heating for more than one hour. Therefore, method for predicting the failure time of structural glued laminated timber columns exposed to fire has not been established yet.

This paper reports on results of load-bearing fire test of structural glued laminated timber columns with Japanese cedar and larch during not only heating phase but also cooling phase. The purpose of the tests was to confirm the properties of charring, the temperature distribution in the cross-section, the deformation behavior and the failure time. Influences of tree type (Japanese cedar, Japanese larch), cross-sectional dimension (300 mm square, $450 \mathrm{~mm}$ square), heating time (30min, 60min, 90min), and load ratio (1, 2/3, 1/3: the permanent allowable design load) on the load bearing capacity in fire were discussed. The failure time from the test result was compared with that of the calculated result by the buckling strength on the basis of tangent modulus theory and mechanical properties at high temperature in accordance with Eurocode5. The follow conclusions could be indicated from this research.

(1) Failure time of cedar columns was shorter than that of larch columns because the cross-sectional reduction of cedar columns during cooling phase were larger and the internal temperature in cross-section of cedar columns were higher.

(2) Under the same heating time and the load ratio conditions, the failure time of the $450 \mathrm{~mm}$ square cross-section was 2 to 3 times longer than that of the $300 \mathrm{~mm}$ square cross-section.

(3) All specimens which exceeded a slenderness ratio at the time of failure by 51 resulted in buckling failure. The residual rate of cross-sectional secondary moment was considerably lower than that of cross-sectional area, so it was indicated that the columns were more likely to buckling in fire.

(4) It was indicated that the failure time which calculated by buckling strength using tangent modulus theory and mechanical characteristics in high temperature based on Eurocode 5 was equal to or a little shorter than that of the test result. 